Article

\title{
Socioeconomic Factors and Sustainable Forage Crops Production in Turkey Aegean Region: A Multivariate Modeling
}

\author{
Celal Cevher ${ }^{1, *(1)}$ and Bulent Altunkaynak ${ }^{2}$ (D) \\ 1 Field Crops Central Research Institute, Şehit Cem Ersever 9-11, Yenimahalle, Ankara 06170, Turkey \\ 2 Department of Statistics, Faculty of Science, Gazi University, Beşevler, Ankara 06500, Turkey; \\ bulenta@gazi.edu.tr \\ * Correspondence: celal.cevher@tarimorman.gov.tr
}

Received: 6 August 2020; Accepted: 23 September 2020; Published: 30 September 2020

check for updates

\begin{abstract}
The aim of this study is to evaluate the effect of farmers' socioeconomic characteristics on sustainable forage crop production after forage crop subsidies. One of the innovative aspects of the study is the simultaneous modeling of alfalfa, silage corn and vetch production efficiency. For this, the multivariate linear regression model was used. In this way, the effect of socioeconomic characteristics on production is more clearly demonstrated by taking into account the dependency structure between forage crop production. For the study, 487 farmers in the Aegean region, where fodder crops can be produced throughout the year, were interviewed face-to-face and data were collected through a questionnaire. According to the results obtained, it was determined that the width of the land had a positive effect on the increase in alfalfa, silage corn, and vetch production. The number of animals was found to have a positive effect on alfalfa and silage maize production growth. The production of alfalfa was higher in rural farmers, and vetch production was higher in urban farmers. Farmers who do not have non-agricultural income focused on vetch production, and farmers with non-agricultural income focused on alfalfa production. It was seen that the majority of the farmers participating in the study were primary school graduates and lived in rural areas. In general, a significant increase was observed in the production of silage corn, vetch, and alfalfa, respectively. After the subsidies, it was concluded that this increase in the production of silage corn, vetch, and alfalfa was not at a level to meet the amount of forage crops needed by animal husbandry.
\end{abstract}

Keywords: forage crops; sustainability; subvention; socioeconomics; multivariate modelling; Aegean region

\section{Introduction}

Forage crop production is important for meeting the feed requirements of livestock and ensuring soil fertility [1]. One of the most important needs of animal husbandry is the production of forage. The feed requirements of a cattle of $500 \mathrm{~kg}$ body weight, to meet the nutrient requirement, are $4 \mathrm{~kg} / \mathrm{day}$ of good quality dry matter and $10 \mathrm{~kg} /$ day of good quality green grass or silage corn [2]. In this context, as the number of animals increases, the need for feed increases. In animal production, feed inputs make up about $70 \%$ of the total production cost.

Turkey is conducive to small and large cattle-breeding because it has natural resources and favorable ecological conditions. Livestock, especially cattle and sheep, is an important component of farming systems in every region of Turkey. However, forage production in Turkey is not at a level that will meet the needs of the animals [2,3]. Alfalfa (Medicago sativa L.), silage corn (Zea mays L.), and vetch (Vicia sativa L.) are the most widely produced forages in Turkey. According to Turkish 
Statistical Institute data (TurkStat, Ankara, Turkey, 2019), alfalfa, silage corn, and vetch, respectively, $641,212.8,507,412.7$ and 391,498.0 are cultivated in hectares (ha). The yields for these products were 28.0 tons/ha for alfalfa, 50.6 tons/ha for silage corn, and 11.0 tons/ha for vetch, respectively. On the other hand, according to TurkStat data, the number of bovine animals is about 14.2 million, the number of ovine animals is reported as 4.49 million [4]. While the feed requirement of these animals is about 95.6 million tons, total forage crop production is about 55.5 million tons. When 11.7 million tons of feed production from meadows and pastures are added, the forage deficit, which was reported as 28.4 million tons in 2019, could not be completed [5]. Farmers producing forage crops have been supported since 2002 in order to provide forage crops needed by livestock. Despite the agricultural subsidies provided to producers, the targeted feed crop production level could not be reached, indicating that these subsidies are not sufficient [5]. Accordingly, studies have been conducted to investigate the effect of subsidies on forage production [6-11]. These studies are generally aimed at examining the effects of macroeconomic variables on forage crop production. However, there is a limited number of studies on forage crop yield that have considered the socioeconomic structures of farmers [12,13]. It is known that socioeconomic characteristics of farmers affect agricultural information that has a high impact on production [14]. In addition, it has been observed that socioeconomic characteristics have an impact on farmers' adoption and use of new technologies $[15,16]$.

The effects of farmers' socioeconomic characteristics on the variables, such as production, yield, technology adoption, and income, have been demonstrated by various studies [17-22]. No studies, however, on socioeconomic variables that affect the production and production patterns of forage crops after the subsidies were found in the time interval of this study. Forage crop supports have been given to farmers since 2002. Therefore, the effect of supports on forage crop production was examined between 2002 and 2015. Farmers can produce more than one forage crop within the production pattern. It is important to examine the effect of subsidies in more detail in order to determine which forage crops farmers choose, how much yield they have, and what socioeconomic characteristics affect this yield. On the other hand, farmers can change their production patterns in the following years, according to their forage support policies. For example, a farmer who sown alfalfa in his entire field, next year, could sow alfalfa in half of his field and silage corn in half. Therefore, there is a dependency, that is, a correlation between the support received by the farmer per hectare and the amount of forage crops. Regarding this relationship, if each of the variables that will affect the amount of forage crop production is examined separately for the forage crop, it may lead to the lack of real relationships or the emergence of non-causal relationships.

The objectives of this study were: (1) to determine the socioeconomic variables that affect farmers' alfalfa, silage corn, and vetch production patterns and (2) to compare the pre- and post- support forage crop production amounts.

\section{Materials and Methods}

\subsection{Study Area and Sampling}

In Turkey, the Eastern Anatolia Region ranks first in terms of acreage for forage crops and intensity of their farming activities (35.15\%), while the Aegean Region (our study area) ranks third with about $15 \%$. However, when the planting area of forage crops and the amount of green grass production are examined, the Aegean Region is in the first place with $35,400 \mathrm{~kg} / \mathrm{ha}$ in terms of green grass yield. Since the climatic conditions of the Aegean region are suitable for forage crop production all year round, more yields can be obtained in forage crop production [3]. Therefore, the Aegean region of Turkey, as an important forage crop producing region, has been identified as the study area (Figure 1). The list of names of all the farmers was obtained from the Farmer Registration System. Data were collected by face-to-face surveys of farmers selected with the cluster sampling method. Four hundred eighty-seven participant-farmers who supported the use of certified forage crops in the Aegean region were randomly selected out of 34,944 farmers. In terms of forages in Turkey, most grown forage crops 
are alfalfa, vetch, and silage corn. These three plants constitute the main sources of forage crops to meet the feed needs of livestock. Therefore, in our study, alfalfa, vetch, and silage corn were considered as feed sources.

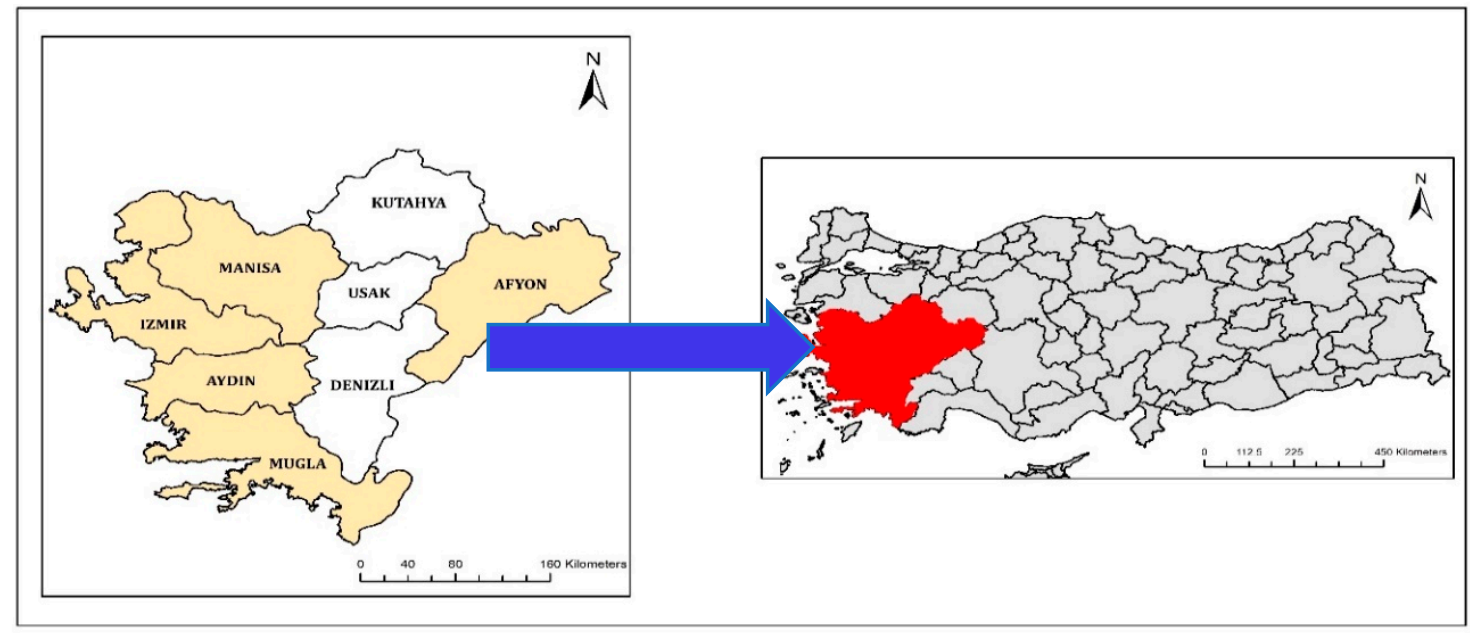

Figure 1. Map of the study area.

\subsection{Farmer Inclusion Criteria}

The study included farmers between the ages of 18-70 and with at least 10 bovine or ovine animals. In addition, since irrigated farming is practiced in a major part of the Aegean region, farmers who produced in irrigated land conditions were taken into consideration in the study. All the farmers included in the study sow forage crop and received state support according to the size of their cropland. At present, there is only a negligible number of woman-farmers in Turkey. Therefore, only male farmers were involved in the study. In this study, the enterprise characteristics of the farmers outside the socioeconomic variables were randomly selected to be homogeneous.

\subsection{Statistical Analysis}

For this purpose, alfalfa, silage maize, and vetch production amounts were considered as dependent variables and the multivariate regression model was used by considering the relationship structures between these variables. The independent variables of the study are the socioeconomic characteristics of the farmer. The production of sainfoin in the Aegean region is almost nonexistent. For this reason, alfalfa (A), silage corn (S), and vetch (V) are considered as roughage plants. The post-support (AS) and pre-support (BS) production differences of these forage crops constitute the dependent variables of the study. Socioeconomic variables, such as age (A), educational status (E), place of residence (PR), non-agricultural income status (I), total land (TL) and the number of animals (NA) belonging to farmers, were used as independent variables. Explanations of the variables are given in Table 1.

Table 1. Data description.

\begin{tabular}{cccc}
\hline Notation & Variable & Type & Description \\
\hline A & Age & Independent & Year \\
E & Education & Independent & $1=$ primary, 2 = middle school, \\
$3=$ high school, $4=$ university \\
PR & Place of residence & Dummy & $0=$ rural, $1=$ city \\
I & Off-farm income & Dummy & $0=$ no, $1=$ yes \\
TL & Total land & Independent & da \\
NA & Number of animals & Independent & Animal Unit \\
$\Delta \mathrm{A}$ & Difference in alfalfa production & Dependent & $\Delta \mathrm{A}=\mathrm{C}_{\mathrm{AS}}-\mathrm{C}_{\mathrm{BS}}(\mathrm{kg} / \mathrm{da})$ \\
$\Delta \mathrm{S}$ & Difference in silage corn production & Dependent & $\Delta \mathrm{S}=\mathrm{S}_{\mathrm{AS}}-\mathrm{S}_{\mathrm{BS}}(\mathrm{kg} / \mathrm{da})$ \\
$\Delta \mathrm{V}$ & Difference in vetch production & Dependent & $\Delta \mathrm{V}=\mathrm{V}_{\mathrm{AS}}-\mathrm{V}_{\mathrm{BS}}(\mathrm{kg} / \mathrm{da})$ \\
\hline
\end{tabular}

Notes: $\mathrm{A}_{\mathrm{AS}}$ : alfalfa production after subsidies; $\mathrm{A}_{\mathrm{BS}}$ : alfalfa production before subsidies; $\mathrm{S}_{\mathrm{AS}}$ : silage corn production after subsidies; $\mathrm{S}_{\mathrm{BS}}$ : silage corn production before subsidies; $\mathrm{V}_{\mathrm{AS}}$ : vetch production after subsidies; $\mathrm{V}_{\mathrm{BS}}$ : vetch production before subsidies. 
The conceptual structure of the multivariate regression model was created as in Figure 2, considering the possibility that the dependent variables may be related among themselves.

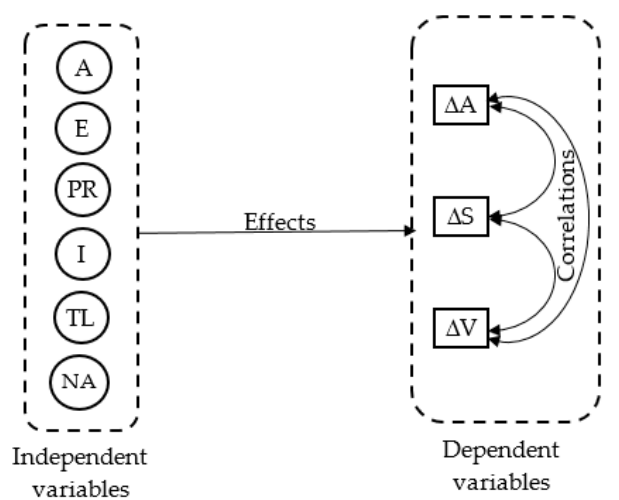

Figure 2. The conceptual model for determination of forage crops production pattern.

The multivariate regression model is used to examine the effect of independent variables on dependent variables, taking into account the covariance structure between dependent variables [23].

$$
Y=X \beta+\varepsilon
$$

where

$$
\begin{gathered}
\mathrm{Y}=(\Delta A, \Delta S, \Delta V)^{T} \\
\mathrm{X}=(1, A, E, P R, I, T L, N A) \\
\beta=\left[\begin{array}{lll}
\beta_{01} & \beta_{02} & \beta_{03} \\
\beta_{11} & \beta_{12} & \beta_{13} \\
\beta_{21} & \beta_{22} & \beta_{23} \\
\beta_{31} & \beta_{32} & \beta_{33} \\
\beta_{41} & \beta_{42} & \beta_{43} \\
\beta_{51} & \beta_{52} & \beta_{53} \\
\beta_{61} & \beta_{62} & \beta_{63}
\end{array}\right]
\end{gathered}
$$

and

$$
\varepsilon=\left(\varepsilon_{1}, \varepsilon_{2}, \varepsilon_{3}\right)^{T}
$$

$\beta$ is a matrix showing the unknown parameters given in Equation (4). In Equation (5), there are assumptions $E\left(\varepsilon_{i}\right)=0$ and $\operatorname{Cov}\left(\varepsilon_{i}, \varepsilon_{j}\right)=\sigma_{i j}$ I. Here, $\sigma_{i j}$ is the covariance between the ith dependent variable and the jth one. Thus, the error terms associated with different dependent variables may be correlated.

In this study, the dependent variables considered are $\Delta \mathrm{A}, \Delta \mathrm{S}$, and $\Delta \mathrm{V}$. Three different linear regression models can be established or a Structural Equation Modeling (SEM) can be created to examine the socioeconomic factors affecting each of these variables. However, in both cases, the covariance between dependent variables is ignored. In SEM models, you can create a covariance between independent, i.e., external variables, but the same is not true for dependent variables that are internal variables. Therefore, multivariate regression analysis was applied in our study. Multivariate regression analysis is a multivariate statistical method that takes into account the covariance between dependent variables. 


\section{Results}

\subsection{Socioeconomic Profile}

The results of the socioeconomic profile are presented in Table 2.

Table 2. Socioeconomic profile.

\begin{tabular}{cccc}
\hline Variable & Level & $\mathbf{M} \pm \mathbf{S D}^{\mathbf{}}$ & $\boldsymbol{n} \mathbf{( \% )}$ \\
\hline Age & - & $48.54 \pm 9.98$ & - \\
\hline \multirow{2}{*}{ Education } & primary & - & $336(69.0)$ \\
& middle school & - & $59(11.5)$ \\
& high school & - & $73(15.0)$ \\
& university & - & $22(4.5)$ \\
\hline \multirow{2}{*}{ Place of residence } & rural & - & $420(86.2)$ \\
& city & - & $67(13.8)$ \\
\multirow{2}{*}{ Off-farm income } & no & - & $304(62.4)$ \\
& yes & - & $183(37.6)$ \\
\hline Total land & - & $115.42 \pm 119.9$ & - \\
\hline Number of animals & - & $23.24 \pm 29.52$ & - \\
\hline
\end{tabular}

$¥$ M: Mean; SD: Standard Deviation.

As Table 2 demonstrates, the average age of the farmers included in the study was $48.54 \pm 9.98$. Approximately seven out of every 10 farmers (69\%) were primary school graduates. Only $4.5 \%$ of the surveyed farmers were university graduates. Farmers predominantly (86.2\%) lived in rural areas. The proportion of farmers whose only income source is agriculture was $62.4 \%$. The average land size owned by farmers is $115.42 \pm 119.9$ hectares. The average number of animals is $23.24 \pm 29.52$.

\subsection{Descriptive Statistics}

Descriptive statistics of dependent variables are given in Table 3.

Table 3. Descriptive statistics.

\begin{tabular}{|c|c|c|c|c|c|c|c|}
\hline \multirow[t]{2}{*}{ Variable } & \multicolumn{2}{|c|}{$\Delta S$} & \multicolumn{2}{|c|}{$\Delta \mathbf{V}$} & \multirow[t]{2}{*}{ Mean } & \multirow[t]{2}{*}{ Standard Deviation } & \multirow[t]{2}{*}{ Normal KS Test $\left(p^{¥}\right)$} \\
\hline & $\mathbf{r}$ & $p$ & $\mathbf{r}$ & $p$ & & & \\
\hline$\Delta \mathrm{A}$ & 0.251 & 0.000 & 0.029 & 0.000 & 65.9 & 13.72 & $0.025(0.200)$ \\
\hline$\Delta S$ & & & -0.016 & 0.000 & 176.8 & 31.72 & $0.031(0.200)$ \\
\hline$\Delta \mathrm{V}$ & & & 1.000 & 0.000 & 125.0 & 25.75 & $0.022(0.200)$ \\
\hline
\end{tabular}

As shown in Table 3 , the correlation between the change in alfalfa production $(\Delta \mathrm{A})$ and the change in silage corn production $(\Delta S)$ after subsidies was significant $(p<0.01)$. The positive correlation coefficient means that after subsidies, alfalfa production and silage corn production increased together. This situation supports the necessity of using the multivariate linear regression model in the study. When average values were analyzed, there were increases in alfalfa, silage corn, and vetch productions after subsidies. The increase was most common in silage corn, followed by vetch and alfalfa, respectively. After subsidies, an average of $65.9,176.8$, and $125.0 \mathrm{~kg}$ increases per hectare were observed in alfalfa, silage corn, and vetch production, respectively. According to the test results in the last column of Table 3, the dependent variables provided the normal distribution assumption.

\subsection{Multivariate Linear Regression Analysis}

The analysis results of the conceptual model given in Figure 2 are presented in Table 4. 
Table 4. Multivariate linear regression results.

\begin{tabular}{|c|c|c|c|c|c|c|c|c|}
\hline \multirow{2}{*}{\multicolumn{2}{|c|}{$\begin{array}{c}\text { Variable } \\
\text { Dependent Independent }\end{array}$}} & \multicolumn{4}{|c|}{ Coefficient Results } & \multicolumn{3}{|c|}{ Model Results } \\
\hline & & Coeff. $(\beta)$ & SE & $t$ & $p$ & $\mathbf{R}^{2}$ & $\mathbf{F}$ & $p$ \\
\hline \multirow{7}{*}{$\Delta \mathrm{A}$} & cons & 1.724 & 5.068 & 0.34 & 0.734 & 0.220 & 22.56 & 0.000 \\
\hline & A & 0.030 & 0.059 & 0.51 & 0.609 & & & \\
\hline & $\mathrm{E}$ & 1.740 & 0.681 & 2.56 & 0.011 & & & \\
\hline & PR & -4.118 & 1.668 & -2.47 & 0.014 & & & \\
\hline & I & 2.799 & 1.163 & -2.41 & 0.016 & & & \\
\hline & TL & 0.032 & 0.005 & 6.58 & 0.000 & & & \\
\hline & NA & 0.118 & 0.020 & 6.04 & 0.000 & & & \\
\hline \multirow{7}{*}{$\Delta S$} & cons & -1.431 & 11.390 & -0.13 & 0.900 & 0.263 & 28.56 & 0.000 \\
\hline & $\mathrm{A}$ & -0.121 & 0.131 & -0.92 & 0.359 & & & \\
\hline & $\mathrm{E}$ & 1.652 & 1.530 & 1.08 & 0.281 & & & \\
\hline & PR & -2.431 & 3.748 & -0.65 & 0.517 & & & \\
\hline & I & -2.742 & 2.613 & 1.05 & 0.294 & & & \\
\hline & $\mathrm{TL}$ & 0.105 & 0.011 & 9.65 & 0.000 & & & \\
\hline & NA & 0.224 & 0.044 & 5.07 & 0.000 & & & \\
\hline \multirow{7}{*}{$\Delta \mathrm{V}$} & cons & -24.313 & 10.011 & -2.43 & 0.016 & 0.137 & 12.66 & 0.000 \\
\hline & $\mathrm{A}$ & 0.165 & 0.115 & 1.43 & 0.153 & & & \\
\hline & $\mathrm{E}$ & -0.646 & 1.344 & -0.48 & 0.631 & & & \\
\hline & PR & 10.437 & 3.294 & 3.17 & 0.002 & & & \\
\hline & I & -7.281 & 2.297 & 3.17 & 0.002 & & & \\
\hline & $\mathrm{TL}$ & 0.069 & 0.010 & 7.12 & 0.000 & & & \\
\hline & NA & -0.023 & 0.039 & -0.60 & 0.547 & & & \\
\hline
\end{tabular}

As shown in Table 4, it was observed that farmer's educational status, place of residence, non-agricultural income status, total land, and the number of animals were effective on the difference $(\triangle \mathrm{A})$ in alfalfa production before and after subsidies. Educational status, total land size, and number of animals positively affected increasing alfalfa production $(p<0.05)$. After the support, rural farmers had a change in alfalfa production, producing about $42.0 \mathrm{~kg}$ per hectare higher compared to those living in the city $(p<0.05)$. Similarly, after subsidies, alfalfa production was increased by about $28.0 \mathrm{~kg}$ per hectare for farmers with non-agricultural income, as compared to farmers without non-agricultural income $(p<0.05)$. Silage corn production $(\Delta S)$ after subsidies was affected by total land and the number of animals with increased yield $(p<0.05)$. It was observed that the place of farmer's residence, non-agricultural income status, and total land were effective on the difference in vetch production $(\Delta \mathrm{V})$ before and after subsidies. In city farmers, after the subsidies, the change in vetch production was about $104.4 \mathrm{~kg}$ more per hectare compared to rural residents $(p<0.05)$. Similarly, in farmers without non-agricultural income, the change in vetch production after subsidies was about $73.0 \mathrm{~kg}$ more per hectare than farmers with non-agricultural income $(p<0.05)$.

\section{Discussion}

Despite the support of forage plants in Turkey, the production of fodder crops has not achieved the desired level. This situation made it important to determine the factors affecting the production increase. At this point, especially examining the socioeconomic characteristics of farmers can provide necessary measures to increase the level of production.

In this study, it was seen that most of the farmers are primary school graduates, that is, they have a low education level. Education is a productive value in agriculture because the farmer may be more skilled at managerial decisions on product selection and purchasing $[20,24]$. In addition, it was observed that a large part of the farmers lived in rural areas. This situation brings the farmers away from the current and technological information. For this reason, training activities for farmers should be emphasized and current information about the importance of forage crops and the techniques for growing them should be given. 
A significant increase was observed in the production of alfalfa, silage corn, and vetch after subsidies. This increase occurred mostly in silage corn followed by vetch and alfalfa, respectively. In the Aegean region, almost all of the existing cattle are made up of culture race animals. Culture race animals prefer roughage with high protein and crude fiber content. The low cost of roughage increases the profitability of livestock enterprises. For this reason, the livestock farms in the Aegean region have gone on to increase the production of alfalfa, silage corn, and vetch in accordance with the ecology of the region. The ecological structure of the Aegean region is suitable for the cultivation of alfalfa, silage maize, and vetch, which are among the quality roughages. The fact that silage corn and vetch production was one-year roughage production and alfalfa production was a perennial forage plant affected the preference of farmers in roughage production. This situation causes the farmers to prefer the annual plants in order to benefit more from the subsidies. It has been observed that the width of land is important in the production of alfalfa, silage corn, and vetch.

It is known that as the amount of land increases, agricultural production also increases [20]. As the amount of land increases, farmers benefit more from the supports and cultivate more forage crops. The number of animals was effective on the increase in alfalfa and silage maize production. Dairy farming is widespread in the Aegean region and alfalfa is an important forage plant for every period of dairy cattle. From the nutritionally rich alfalfa plant, $8-10$ harvests can be obtained annually in regions such as the Aegean and South Anatolia. In addition, in order to increase the meat and milk yield in the winter season, the green forage plants abundant in other seasons should be stored by silage. The silage feed used in animal husbandry is mostly obtained from corn plants in Turkey [25]. Therefore, as the number of animals increases, farmers are expected to increase their production of alfalfa and silage corn.

Considering the place where the farmer lives, it is determined that the increase in alfalfa production in rural farmers is $42.0 \mathrm{~kg} / \mathrm{ha}$ more than the ones living in the city. On the contrary, in farmers living in the city, the increase in vetch production is $104.4 \mathrm{~kg} / \mathrm{ha}$ more than those living in rural areas. As the farmer producing alfalfa spends more effort and time than the farmer producing vetch, it can be said that the farmers who live in rural areas prefer alfalfa production and the farmers who live in the city prefer to produce vetch, which requires less labor and time. In addition, since vetch production requires less cost than alfalfa production, it has been determined that farmers without non-agricultural income tend to produce vetch. On the other hand, it has been determined that farmers with non-agricultural income tend to produce alfalfa.

One of the important factors in increasing the amount of forage crop production is increasing the available forage crop supports. Farmers will also earn more income from other crop production by increasing the amount of forage crop support. This situation will naturally cause an increase in forage crop cultivation area in agricultural enterprises. In addition, providing farmers with up-to-date information on forage crop cultivation techniques may trigger an increase in production. One of the important results obtained in this study is the positive effect of enterprise scale on forage crop production area. According to the results of the model, a one-unit increase in the size of the farmland leads to an increase of 0.03 units in alfalfa, 0.10 units in silage corn and 0.07 units in vetch, respectively, in terms of production area. This result proves that enterprises with a large enterprise scale are advantageous in terms of the production of forage crops, which is the most important cost element of animal husbandry. This can be evaluated as an advantage of positive scale economy.

\section{Conclusions, Limitations, and Future Research Directions}

The production of forage crops and the amount of roughage obtained in pasture-pasture areas is not sufficient to meet the needs of sheep and cattle breeding in Turkey. In order to provide quality feed, which has become the most important problem of animal husbandry, it is important to take some precautions as soon as possible and to apply them carefully in order to improve the culture of forage crops in the field agriculture and meadow and pasture areas. There is a similar situation in the Aegean Region. When the climate conditions of the Aegean Region and the condition of the 
meadows and pastures are evaluated, the studies on forage crops and pasture presence should be given priority. With the training activities to be organized on a regional basis, forage crop cultivation should be encouraged, and updated information should be provided to producers on the importance of forage crops and growing techniques. In addition, support should be given to the production of alternative fodder crops that can support roughage production. In addition to the gradual increase of supports, the development of an appropriate support policy is also important for increasing forage crop production. Forage crop yield per hectare received in Turkey, which supports forage crops showed differences by region of fodder crops are given according to the size of arable land. This situation causes dissatisfaction among farmers. For this, supports can be applied in different ways depending on the regions or support can be made on the yield per hectare. We anticipate that improving this situation will significantly increase forage crop production. On the other hand, we suggest that it is important to provide frequent training to existing farmers.

No study is without limitations, and this study has some limitations and requires further scientific inquiry. First, as this study included only Aegean Region to collect data, these results cannot be generalized to all of Turkey, however, can be helpful to understand the behavior of sustainable forage crop production. Second, we think that working with more or different independent variables will increase the coefficient of determination. However, since this study focused only on the socioeconomic characteristics of the farmers, we had to keep the independent variables in a limited number, and we benefited from the literature while determining these variables. Third, while the research methodology adopted in this paper provided the collection of information with an adequate depth that met the paper's objective, the study would have been richer if a more extensive data collection methodology was used. We relied on a cross-sectional study approach that built on a farmer survey. A more extensive data gathering approach, such as a panel data study, would have provided more information. Finally, more detailed investigations can be made with techniques such as logistic regression analysis to examine the increase in forage crop production before and after support.

Author Contributions: conceptualization, C.C.; methodology, C.C., and B.A.; software, B.A.; validation, C.C., and B.A.; formal analysis, B.A.; writing-original-draft preparation, C.C., and B.A.; writing-review and editing, C.C., and B.A. All authors have read and agreed to the published version of the manuscript.

Funding: This research received no external funding.

Acknowledgments: We are grateful for the unbelievably valuable comments of three anonymous reviewers and the Academic Editor. We thank the forage producers, agricultural institutions, and organizations in Aegean region from which we received the primary data of the study.

Conflicts of Interest: The authors declare no conflict of interest.

\section{References}

1. Kosolapov, V.; Rud', V.; Korshunov, A.; Savchenko, I.; Switala, F.; Hogland, W. Scientific support of the fodder production: V.R. Williams All-Russian Fodder Research Institute (WFRI) activity. IOP Conf. Ser. Earth Environ. Sci. 2019, 390, 012010. [CrossRef]

2. Alçiçek, A.; Kılıç, A.; Ayhan, V.; Özdoğan, M. Türkiye'de kaba yem üretimi ve sorunlari. In Proceedings of the Türkiye Ziraat Mühendisliği VII Teknik Kongresi, Ankara, Turkey, 11-15 January 2010; pp. 1071-1080.

3. Topçu, G.D.; Özkan, S.S. General view to meadow-rangelands and forage crops cultivation of Aegean Region and Turkey. COMU J. Agric. Fac. 2017, 5, 21-28.

4. Ozkan, U. Comparative Overview and Evaluation of Turkey's Forage Crops Agriculture. Turk. J. Agric. Eng. Res. 2020, 1, 29-43.

5. Acar, Z.; Tan, M.; Ayan, İ.; Aşçı, Ö.Ö.; Mut, H.; Başaran, U.; Gülümser, E.; Can, M.; Kaymak, G. Türkiye'de Yem Bitkileri Tarımının Durumu ve Geliştirme Olanakları. In Proceedings of the Türkiye Ziraat Mühendisliği IX. Teknik Kongresi, Ankara, Turkey, 13-17 January 2020; pp. 529-553.

6. Yavuz, G.; Ceylan, İ.C. Polatlı ilçesinde üreticilerin yem bitkileri üretimine karar verme sürecinde etkili faktörlerin belirlenmesi üzerine bir araştırma. Tarım Bilimleri Derg. 2005, 11, 133-138. 
7. Asskan, E.; Dağdemir, V. Devlet desteklemelerinden faydalanan süt sığırcılığ1 yapan işletmelerin üretim değerini etkileyen faktörlerin analizi: Erzurum, Erzincan, Bayburt illeri örneği. Turk. J. Agric. Econ. 2015, 21, 69-76.

8. Saygı, Y.D.; Alarslan, Ö.F. Kaba yem destekleme uygulamalarının Yozgat yöresi süt sığırı yetiştiriciliğine etkileri. Vet. Hekimler Dern. Derg. 2012, 83, 25-35.

9. Ahn, B.; Han, S. Analysis on the effects of government's support for forage production. Korean J. Agric. Econ. 2016, 57, 55-78.

10. Chang, J.B. The effects of forage policy on feed costs in Korea. Agriculture 2018, 8, 72. [CrossRef]

11. Aksu, N.; Dellal, İ. Afyonkarahisar ilinde yem bitkileri desteğinin büyükbaş hayvancılık faaliyetleri ile ilişkisinin değerlendirmesi. Yüzüncü Yıl Üniv. Tarım Bilimleri Derg. 2016, 26, 52-60. [CrossRef]

12. Karadavut, U.; Genç, A.; Palta, Ç.; Çarkacı, A.; Kökten, K. Konya İli Yem Bitkileri Üreticilerinin Sosyo-Ekonomik Yapıları İle Başarılı Üretimi Etkileyen Faktörlerin Belirlenmesi. Bingöl Üniv. Fen Bilimleri Derg. 2011, 1, 1-12.

13. Aydoğdu, M.; Aydoğdu, İ.; Cevheri, C.; Sevinç, M.R.; Küçük, N. Şanlıurfa'daki yem bitkileri eken çiftçilerin sosyo-ekonomik profilinin analizi. J. Ekon. 2020, 0, 10-15.

14. Rehman, F.; Muhammad, S.; Ashraf, I.; Ruby, T. Effect of farmers' socioeconomic characteristics on access to agricultural information: Empirical evidence from Pakistan. J. Anim. Plant Sci. 2013, 23, 324-329.

15. Matata, P.; Ajay, O.; Oduol, P.; Agumya, A. Socio-economic factors influencing adoption of improved fallow practices among smallholder farmers in western Tanzania. Afr. J. Agric. Res. 2010, 5, 818-823.

16. Cruz, F. Adoption and diffusion of agricultural extensions. In An Introduction to Extension Delivery Systems; Valera, J.B., Martinez, V.A., Plopino, R.F., Eds.; Island Publishing House: Manila, Philippines, 1987; pp. 97-127.

17. Feder, G.; Just, R.E.; Zilberman, D. Adoption of agricultural innovations in developing countries: A survey. Econ. Dev. Cult. Chang. 1985, 33, 255-298. [CrossRef]

18. Baffoe-Asare, R.; Danquah, J.A.; Annor-Frempong, F. Socioeconomic factors influencing adoption of CODAPEC and cocoa high-tech technologies among small holder farmers in Central Region of Ghana. J. Exp. Agric. Int. 2013, 3, 277-292. [CrossRef]

19. Alam, M.; Siwar, C.; Talib, B.; Toriman, M. The relationships between the socioeconomic profile of farmers and paddy productivity in North-West Selangor, Malaysia. Asia Pac. Dev. J. 2011, 18, 161-173. [CrossRef]

20. Anigbogu, T.U.; Agbasi, O.E.; Okoli, I.M. Socioeconomic factors influencing agricultural production among cooperative farmers in Anambra State, Nigeria. Int. J. Acad. Res. Econ. Manag. Sci. 2015, 4, 43-58. [CrossRef]

21. Moloi, M.J. A Comparison of Socioeconomic Characteristics that Determine the Farm Income of Emerging Lifestock and Horticultural Farmers in South Africa; University of Limpopo: Polokwane, South Africa, 2010.

22. Ademiluyi, S.; Oladele, O.I.; Wakatsuki, T. Socioeconomic factors influencing power tiller use among Sawah farmers in Bida, Nigeria. J. Food Agric. Environ. Finl. 2008, 6, 387-390.

23. Johnson, R.A.; Wichern, D.W. Applied Multivariate Statistical Analysis, 3th ed.; Prentice Hall International: Englewood Cliffs, NJ, USA, 1992.

24. Fane, G. Education and the Managerial Efficiency of Farmers. Rev. Econ. Stat. 1975, 57, 452-461. [CrossRef]

25. Şahin, İ.F.; Zaman, M. An Important Cattle Feed: Silage. Doğu Coğraf. Derg. 2010, 15, 1-18.

(C) 2020 by the authors. Licensee MDPI, Basel, Switzerland. This article is an open access article distributed under the terms and conditions of the Creative Commons Attribution (CC BY) license (http://creativecommons.org/licenses/by/4.0/). 